\title{
Class-Against-Class and the Red Trade Union Opposition
}

One of the topics raised at the Fifth Conference of the IPC-TW in 1928 was the need to organise a World Congress of Transport Workers. The delegates supported the plan but its implementation had to wait for the realisation of another idea, namely the establishment of a new special designed radical umbrella organisation, namely an International for (revolutionary) Transport Workers. Delegates representing English, French, Irish, and Soviet transport workers' unions had raised the idea at a meeting held in Moscow in September 1927..$^{1}$ The proposal was discussed at the Fifth Conference but was not publicised through an official declaration, most probably because the Moscow headquarters had not made any preparations or had not managed to draft a resolution on the topic. In addition, the transition to and implementation of the 'United front from below'-tactic, not least the directive to consolidate the revolutionary trade union opposition groups, dominated the agenda for the next years to come. Two positions of how to organise work crystalised, one putting the revolutionary nuclei in the forefront while the other one focussed on either organising the opposition within the existing unions or establishing new red unions.

\section{Walter's Position: "You Have to Start from the Bottom"}

The organisation of revolutionary nuclei, namely sea and ship cells, had been the bravura of Albert Walter and the Hamburg Interclub. He and his associates had put all their energy in achieving this task and had been rather successful in doing so. The strategy had resulted in the establishment of a strong communist sea cell, the Seezelle Hamburg, that dominated the revolutionary fraction of the Hamburg section of the German Transport Workers' Federation. Communist agitation and propaganda activities expanded to other German ports in 1928,

1 "Tätigkeitsbericht des IPAK," in Die 5. Internationale Konferenz der Revolutionären Transportarbeiter, 18. 
and sea cells were successively created in Bremen, Bremerhaven, Cuxhaven, Kiel and Lubeck. ${ }^{2}$

Walter had repeatedly criticised the functionaries of the Interclubs and the revolutionary minority groups outside Germany for neglecting or downplaying the importance of forming revolutionary nuclei. In his mind, the "from the bottom" or grassroots level approach was to yield best results, namely engaging with the seamen in person, convincing them about the objectives of the revolutionary opposition, and building up a network of trusted persons. This ought to be top priority for all revolutionary units, he argued. Unless the formation of sea and ship cells was not hastened, there was no point of pushing for a new International, Walter reasoned. ${ }^{3}$

Walter's lukewarm position towards the envisioned new International might reflect his stance on the radicalisation of communist trade union activities in Germany. His attitude differed from the general urge of forming independent red trade unions in Germany, the Revolutionäre Gewerkschaftsopposition (RGO; Revolutionary Trade Union Opposition). The beginning was set in 1928 when the opposition within the unions tried to form own strike committees and tried to form a unified block in union elections. The social democraticcontrolled unions, in turn, countered these tendencies by dismissing its most militant members. Among others, the seamen's section of the German Transport Workers' Federation silenced the radical opposition by expelling Walter and three other communists from its ranks. ${ }^{4}$ However, in contrast to other leaders of communist trade union opposition groups, Walter did not push for the formation of an independent red seamen's union in Germany. Rather, one could argue that his initial tactics relied on working through comrades of the Seezelle Hamburg who were still members of the union. In addition, his "from the bottom"-approach relied heavily on engaging unemployed seamen in the union. This was contested by the union leadership as unemployed or jobless seamen were seldom capable of paying their membership fees and were therefore not considered full, if at all, members of the union. The crux of the matter was the right to vote: Was it limited to fee-paying members as the union leadership declared or had unemployed ones who once had been members the right to vote? Communist tactics of including unemployed/jobless members clashed with the position of excluding them that dominated among the union leadership. For communist agitators such as Walter, the unemployed

2 Internationales Hafenbüro Hamburg, Jahresbericht 1929, 534/5/211, 103, RGASPI.

3 Sitzungsbericht, no date [stamped 12.2.1929], 534/5/210, 28, RGASPI.

4 Internationales Hafenbüro Hamburg, Bericht Februar 1928, 534/5/201, 27, RGASPI. The three other expelled members were K. Lesse, F. Dalmar and A. Rath. 
constituted a reservoir of potential militant and radical members who had to be captured by the revolutionary opposition.

The focus on forming revolutionary nuclei remained the prime obligation of the Hamburg Interclub in 1929. In September, Wall Street crashed and world shipping slumped by the end of the year, followed by global crisis, depression and rising numbers of unemployed in 1930. The Hamburg waterfront was hard hit. More than 20,00o harbour workers had a job in 1929, one year later only 15,500. German shipping industry plunged and about 12,500 out of 50,00o mariners were unemployed at the end of 1930 . Walter's tactic on focusing on work among unemployed seamen paid off - the local revolutionary trade union opposition increased to 714 members of which 250 were members in the party. The Seezelle Hamburg, in turn, listed 630 members. ${ }^{5}$

Walter's tactical considerations might explain the slow pace of forming an independent red union for maritime transport workers in Germany. Interestingly, Walter never raised the issue in his (identified) correspondence with Achkanov and the IPAC-Tw headquarters in Moscow. Walter had definitively adopted the vocabulary of the 'Class-Against-Class'-doctrine: The social democratic union leaders were denounced in his letters and reports as 'social fascists'. He certainly adhered to the new strike tactics, i.e., the Strassburg Theses, of forming communist-led strike committees, and called for a 'United front from below'. Nevertheless, no red seamen or maritime transport workers' union had been established by 193 .

\section{2 Organising the Opposition within or outside the Unions?}

The singularity of Walter's focus on the top priority of forming revolutionary nuclei stands in contrast to the dominant strategy of either consolidating the revolutionary opposition within the unions or establishing independent red union. The strategy contained two interlinked parts. First, the consolidation of the revolutionary opposition remained the prime target after 1928. Second, the establishment of independent red unions was a necessarily consequence if the 'United front from below'-tactic had failed. Revolutionary opposition groups existed in most, if not all unions, the novelty of the new strategy was to formalise and organise the opposition under communist leadership. The quintessence of the new strategy was the application of so-called confrontation tactic. This implied that the opposition was to attack and denounce the union

5 Internationales Hafenbüro Hamburg, Jahresbericht 1930, 534/5/216, 77-82, RGASPI. 
leadership and its non-communist functionaries whenever possible as 'traitors of the working class', 'supporters of the bourgeois exploiters', and 'social fascists'.

An idea of the application of the new strategy is found in a rare document on the establishment of revolutionary trade union opposition groups in Sweden. Intra-union conflicts and clashes were blamed on the 'reformist trade union leaders' whose activities had caused a rift in the union. The existing opposition groups, however, were weak and unorganised and therefore in need for a total systematic overhaul if they were to achieve the capacity to organise, release and lead the 'fight of the working class'. The new unit to be established was the 'red union opposition' (Röd facklig opposition, RFO) and to be composed of the opposition groups on the working places and in the existing unions. The RFO was not envisioned to constitute an independent organisation with its own statutes and members, the directives stressed, as this could provoke counter-measures by government authorities and the unions and would lead to the expulsion of RFO-members. Instead, the directives ordered to utilise so-called 'half-legal' methods in their work, namely to organise meetings but camouflage them as study circles, radio associations or 'special committees'. Leaflets and flyers were never to be distributed in public on the workspaces but to be discretely placed on the tables in dining halls and lunchrooms, or put in jackets hanging in the cloakrooms. On the other hand, the RFO should not make a secrecy of its existence, it should sign the leaflets and organise demonstrations and mass meetings and appear as a single, unified group at union meetings. ${ }^{6}$

Nevertheless, the formation of RFO-units in the Scandinavian maritime unions was a slow process. The split of the Communist Party in Sweden shattered the erstwhile strong position of the communists in the seamen's and stokers' unions, and the activities of the Comintern-loyal minority had to start from scratch in late 1929. From spring 1930 onwards, the confrontation tactic applied by the minority-communist-led opposition gained momentum, resulting in the expulsion of two of its leaders, Knut Björk and Bernt Svenson. By the end of the year, the RFO increased its public agitation by publishing its own journal, Hamn- och Sjöproletären. ${ }^{7}$

The situation was also complicated in Denmark and Norway. As the communists had a profound influence in the Danish stokers' union, they reorganised

6 Draft text about instructions for organising the red union opposition (Instruktion for RFO:s uppbyggande), no date, Handlingar rörande fackliga frågor, $\mathrm{R} / 7 / \mathrm{F} / 3$, ARAB. The text was probably written in 1929/1930. See further Weiss, För kampen internationellt!, 111-116.

7 Weiss, För kampen internationellt!, 282-283. 
themselves as a RFO as late as 1931. About the same time, the opposition formed a RFO within in the Danish Seamen's Union. Positive conditions for communist agitation also existed in Norway. Artur Samsing had returned to Oslo in early 1929 and immediately started to form an RFO within the Norwegian Seamen's and Stokers' Union, the Sjøfolkens Revolusjonære Fagopposition. A few months later, the RFO had established branches in Bergen, Haugesund, Stavanger and Tromsø, one year later in Porsgrunn and Tønsberg. Moreover, Samsing had contacts with 67 ship cells. The union reacted promptly: Samsing was excluded already in mid-1929. ${ }^{8}$

The course of events in the Scandinavian countries exemplifies the process of forming RFO-units within maritime transport workers' trade unions. Their implementation of the 'United front from below'-tactic was an intra-union affair and focused on replacing the union leadership with members of the opposition. In other countries, such a France, Greece and the USA, the confrontation and 'United front from below'-tactic provoked split and division within the unions and resulted in the establishment of independent red or so-called unitary unions.

\section{$3 \quad$ Exit Port Bureau, Enter Interclub}

The readjustment and revision of IPAC-TW strategies in 1928/29 also affected the Port Bureaus and Interclubs. The former had hitherto constituted the backbone of the previous IPC-TW to influence the maritime transport workers' unions. The Port Bureau served as operational nodes for local agitation while the Interclub was one of the Port Bureau's arenas of action. All units planned and established before 1928 had been Port Bureaus. All of them complained repeatedly about the lack of space for running a proper Interclub, most of them managed to solve this limitation and were capable of expanding their range of operations. Then, for reasons discussed in Chapter 4.2.3, most of the Port Bureaus were closed in 1928, including those in Bordeaux, Copenhagen and Rotterdam. The only remaining Port Bureaus apart from those in the Soviet ports existed in Hamburg and Marseille.

The closure of the Port Bureaus did not imply the termination of communist waterfront activities. On the contrary, members of the local revolutionary opposition had set up International Seamen's Clubs or Interclubs, sometimes in assistance by the party; the first one being the New York Interclub

8 Weiss, För kampen internationellt!, 268, 271, 275-276, 282-283. 
established in 1928. An Interclub lacked the hidden space of the Port Bureau; it was a public space open for any visitor. Some of them even included a backstage office. All of them had been established without the direct (or indirect) input of the IPAC-TW, none would send monthly or annual activity reports and financial balances to the IPAC-TW Secretariats or headquarters in Moscow. A loose network of internally unconnected nodes in the solar system of the IPAC-TW emerged with the establishment of the New York Interclub. The Interclubs constituted a mere list of places a radical maritime transport worker was invited to visit but whose operations and activities were controlled by its local management (and at times, the local party functionaries), not the IPACTw: Bremen, Esbjerg, Marseille, Philadelphia, Sydney ...

\section{Towards an International of Transport Workers?}

The RILU Executive Bureau summoned for a meeting in Moscow in January 1930. On top of its agenda was the transformation of the largest and most effective International Propaganda Committees into outright Internationals. The reason for this step was obvious: Internationals with member sections were believed to be more effective organisations to carry out the Strassburg Theses' directives on establishing independent strike committees than the International Propaganda Committees. Also, the implementation of the 'ClassAgainst-Class'-doctrine and the 'United front from below'-tactic was believed to be more effective by an International and its sections, the national revolutionary union oppositions, as they were to constitute the counterparts to the International Trade Secretariats and their national member unions. ${ }^{9}$

The RILU Executive Bureau identified the IPAC-TW to be best suited for a gradual transformation into an International. Leif Foss and Albert Walter were instructed to start the preparations by orchestrating an international campaign among the transport workers to push for the establishment of a counter-organisation to the ITF at the meetings of their national unions. The IPAC-TW headquarters was ordered to publish a brochure on the need for an International while Walter was directed to prepare a blueprint for grass-roots agitation and propaganda. The core idea was to "expose" the social democratic trade union leaders as well as the ITF for siding with the employers and the shipping industry, not least for advocating the use of blacklegs. ${ }^{10}$

9 See further Tosstorff, The Red International of Labour Unions.

10 Letter (in German) to "Lieber Freund," 20.1.1930, 534/5/216, 3, RGASPI. The sender was most likely someone at the IPAC-TW headquarters, the recipient probably Albert Walter. 
Walter received additional information from Achkanov at the end of January 1930. The idea of establishing a Transport Workers' International was still on the table, and Achkanov briefed Walter that the plan was up for discussion at the forthcoming Fifth World Congress of the RILU in July 1930. However, Achkanov told Walter that he had received a competing proposal by "the Americans, English and Scandinavians" to establish a special organisation for the radical seamen. Achkanov himself was not negative about the idea and asked for Walter's opinion about launching a Seamen's International instead of one for all transport workers. ${ }^{11}$ Walter's reply is not known but his activities during the first half of 1930 points to the fact that preparations for the launching of a new organisation were in full swing.

\subsection{Regional Conferences for the River Rhine and the Black Atlantic}

The Hamburg Port Bureau and Interclub evolved as the central node of activities for the IPAC-TW and the RILU in 1930. Work among foreign seamen intensified and had resulted in the establishment of new sea cells in London, New York and Oslo. Communist agitation and propaganda on the Hamburg waterfront was met by stiff countermeasures by the Christian seamen's missions and the local police - the former increased their outreach in the harbour, the latter increased its pressure on the Interclub and arrested 40 seamen when it raided the Interclub on 1 February. ${ }^{12}$ The raid evoked an international outcry against "the brutality of the social fascists' bloodhounds" in the communist press. ${ }^{13}$ The German shipowners, especially the HAPAG in Hamburg and the Norddeutscher Lloyd in Bremen, tried to counteract communist infiltration on their vessels by calling the right-wing Stahlhelm organisation as well as Nazi groups to form units on board their steamers. The increase of fascist leaning German mariners raised concern among the communists, and Walter noted that 77 out of 187 seamen who had registered to vote in the German Reichstag election of 1930 had supported the Nazis, 48 the SPD and only 27 the KPD. ${ }^{14}$

Meanwhile, Walter managed to organise a conference of the maritime transport workers along River Rhine in Duisburg on 1-2 February 1930. Present were

11 [Achkanov?] to 'Lieber Freund', [Moscow] 27.1.1930, 534/5/214, 49, RGASPI.

12 Internationales Hafenbüro Hamburg, Monatsbericht Februar 1930, 534/5/216, 14-15, RGASPI.

13 See "Socialfascisternes Blodhunde i Hamborg angriber International Sømandsklub," Lanternen 2:5 (Februar 1930), 1.

14 Internationales Hafenbüro Hamburg, Monatsbericht August-September 1930, 534/5/216, 67, RGASPI; Internationales Hafenbüro Hamburg, Monatsbericht November 1930, 534/5/ 216, 70, RGASPI. 
delegates from German (Bremen, Emden, Duisburg, Düsseldorf, Hamburg, Cologne, Mannheim and Minden), Dutch (Rotterdam) and Swiss (Basle) ports as well as the Free Town of Danzig. Originally projected by the IPAC-TW to summon already in $1929,{ }^{15}$ its main achievement was an agreement on prospective trans-regional cooperation. Although the immediate practical outcomes of the conference were slim if not nil, the delegates gave their full backing of establishing an Interclub in Duisburg-Ruhrort. ${ }^{16}$

Back in Hamburg, the German transport union rejected the call of the revolutionary opposition for a new International. ${ }^{17}$ This came as no surprise for the comrades in Moscow who did not regard the decision of the German union as a setback. On the contrary, communist publications termed the rejection as proof of the 'social fascist' inclinations of the union leadership, and fervently highlighted the need to establish an 'independent', i.e., red Seamen's International. ${ }^{18}$ However, other setbacks in Hamburg in late spring and early summer 1930 were more problematic. The Norwegian functionary of the Interclub had been expelled, the Chinese comrade Liao Chenghzi was wanted by the police, and three other Interclub functionaries had been arrested. ${ }^{19}$

Documentation is patchy about when the decision was made in Moscow to organise a conference in Hamburg for launching a Seamen's International. Seemingly, it was made sometimes in February/March 1930 although no written directives or publicised calls have yet been identified in the archives. Whatever the case, Walter received in February a note regarding a completely different upcoming event - the forthcoming 'Negro Trade Union Conference'. The sender of the letter was George Padmore, a Trinidad-born and CPUSA-member who had arrived in Moscow in late 1929. Walter was certainly aware of the plans for arranging a conference for black workers; the topic had been on the agenda when James W. Ford visited Hamburg in January 1929 and Walter had backed the plan to summon the conference in Hamburg (see Chapter 4.2.1). However, no further information had been forthcoming and Walter must have

\footnotetext{
15 I.P.A.K.T an die Rheinkonferenz der revolutionären Transportarbeiter, no date [ca. 1929], 534/5/207, 198, RGASPI.

16 Konferenz der Rheinschiffer und Hafenarbeiter in Duisburg am 1. Und 2. Februar 1930, einberufen vom IPAKT, no date [February/1929], 534/5/214, 51, RGASPI.

17 Internationales Hafenbüro Hamburg, Monatsbericht März 1930, 534/216, 17-18, RGASPI.

18 "Alexander" to "Lieber M," 9·3.1930, 534/4/304, 12, RGASPI. The sender can be identified as RILU General Secretary Alexander Lozovsky, the recipient was most probably M[ax Ziese].

19 Internationales Hafenbüro Hamburg, Monatsbericht April 1930, 534/5/216, 21, RGASPI; Internationales Hafenbüro Hamburg, Monatsbericht Mai 1930, 534/5/216, 25-26, RGASPI; Internationales Hafenbüro Hamburg, Monatsbericht Juni 1930, 534/5/216, 38-39, RGASPI.
} 
been rather perplexed about Padmore's notification that the conference was to take place in London. Walter replied to Padmore that the Hamburg Port Bureau only had contact to a few Caribbean and Liberian seamen. Nevertheless, Walter assured Padmore that "I have the pleasure to state that everything will be done to assist you" but at the same time reminded him that he needed "trustworthy addresses at the port of calling, so that our men are not forced to search for hours in order to find someone to whom to deliver the material."20

The arrangement of the 'Negro Trade Union Conference' turned out to be a protracted affair. The decision to organise the conference in London had been made at 'Negro Trade Union Conference' organised by Ford in congruence with the Second World Congress of the League Against Imperialism, ${ }^{21}$ held in Frankfurt am Main in July 1929. The RILU Secretariat authorised Ford's plan at the end of October 1929; ${ }^{22}$ Ford returned to the USA in November 1929 and was replaced by Padmore at the RILU headquarters. This was a strategic move to 'neutralise' the organiser by locating the official headquarters of the organisation in New York and referring to it as the ITUCNW only (i.e., dropping the suffix -RILU). However, due to the rather cryptic response from the British government, i.e. not an outright rejection but neither an acceptance, the organisers changed their plans in May 1930 and decided to move the conference to Hamburg. ${ }^{23}$ The Hamburg Port Bureau together with the West European Bureau of the Comintern in Berlin took care of the practical and technical preparations for the conference scheduled to convene in the premises of the Interclub in early July 1930. ${ }^{24}$

The July 1930 Hamburg Conference resulted in the official establishment of the ITUCNW. Euphorically, the published report of the conference claimed that

$20 \quad$ Walter to Padmore, Hamburg 26.2.1930, 534/5/216, 13, RGASPI. Padmore's letter to Walter is yet to be identified in the Comintern Archives.

21 On the League Against Imperialism, see further Fredrik Petersson, 'We Are Neither Visionaries Nor Utopian Dreamers': Willi Münzenberg, the League against Imperialism, and the Comintern. Lewiston: Queenston Press, 2013.

22 Auszug aus dem Protokoll Nr 62 der Sitzung des Sekretariats der RG I vom 21.10.1929, 534/ 3/450, 87 , RGASPI.

23 Minutes of Meeting of the Trade Union Committee of Negro Workers of the RILU, 29.5.1930, 495/155/63, 96, RGASPI. See further Adi, Pan-Africanism and Communism, 107110; Weiss, Framing a Radical African Atlantic, 229-239.

24 Internationales Hafenbüro der Seefahrer Hamburg, Monatsbericht August 1930, 534/5/ 216, 67-69, RGASPI; Protokoll des We B Nr 77, 11.4.1930, Nr 79, 14.4.1930, Nr 105, 7.7.1930, all filed in RGASPI 499/1/17; Report of Proceedings and Decisions of the First International Conference of Negro Workers (Hamburg: International Trade Union Committee of Negro Workers, 1930), 40; Weiss, Framing a Radical African Atlantic, 240-246. The preparations in Germany are not discussed in Adi, Pan-Africanism and Communism. 
the 17 delegates from the USA, Caribbean and sub-Saharan Africa represented 20,ooo black workers, 7 countries, 11 different trade unions, 2 national trade union centres, one national political party and 2 non-trade union organisations in the USA, the Caribbean, Europe and sub-Saharan Africa. Interestingly, none of them represented black maritime transport workers. ${ }^{25}$

The most notable outcome of July 1930 Hamburg Conference was the reorganisation of work at the RILU headquarters in Moscow. As the ITUCNW was to be presented as a 'new' organisation, the unit in Moscow was renamed as the 'Negro' Bureau of the RILU (and claimed to have existed since 1928) with George Padmore being in charge of the unit. The (new) RILU Negro Bureau, not the ITUCNW, was to be the "ideological leader of the international work among the Negro masses for stimulating the trade union work"; its geographical outreach was the total Black Atlantic, including the USA and Latin America, and was to be composed of representatives from the USA, South Africa, West Africa and the Caribbean. ${ }^{26}$ The objective of the ITUCNW, in turn, was to organise black workers and peasants and to connect them with the RILU and the Peasants' International (Krestintern). ${ }^{27}$ The consequence of the reorganisation in Moscow was the formalisation of a hierarchical relationship between the two organisations with the ITUCNW being subordinate to the RILU Negro Bureau. The ITUCNW was to publish its own journal whereas The Negro Worker remained the official organ of the RILU 'Negro' Bureau. ${ }^{28}$

\subsection{Moscow, July 1930}

Following established practice, the IPAC-TW organised its own conference in conjunction with the Fifth World Congress of the RILU. Held in July 1930, the Sixth Conference of the Revolutionary Transport Workers (hereafter: The Sixth Conference) was remarkably silent about the plans for the transformation of the IPAC-TW into an International lest the ponderations about launching a specific Seamen's International. Neither did the IPAC-TW publish any records nor proceedings of the conference as it had done in 1928. The silence in Moscow can be interpreted as either a strategic manoeuvre or an indication of the

25 Report of Proceedings, 40; Adi, Pan-Africanism and Communism, 110-121; Weiss, Framing Radical African Atlantic: 248-268.

26 ECCI, Resolution on Negro work, 30.8.1930, 495/18/810, 75, RGASPI.

27 ECCI, On the Organisation of the International Trade Union Committee of Negro Workers, 5.9.1930, 495/18/810, 77, RGASPI. See further Weiss, Framing a Radical African Atlantic, 286-288. The two resolutions of the ECCI are not discussed in Adi, Pan-Africanism and Communism.

28 "Statement to our readers," The Negro Worker: Special Number on the Fifth Congress of the R.I.L.U. (1 November 1930): 1. 
uncertainty about the future prospects of the IPAC-TW. Both interpretations seem possible. Typical for the Comintern and the RILU, radical organisations, such as the League Against Imperialism or the International Trade Union Committee of Negro Workers, were portrayed as having emerged as an outcome of a 'mass movement from below' and were described as 'independent'. Any links with Moscow were either blurred or negated. The plan of launching a Transport Workers' or a Seamen's International resembled similar tactical considerations as they were envisioned as the apex or culmination of a world-wide campaign orchestrated by the revolutionary opposition, not the communist fractions. However, what speaks for the uncertainty in Moscow is the existence of two plans for the transformation of the IPAC-TW. While it seems as if the idea of establishing a Seamen's International had gained support and was pushed forward, that of a general Transport Workers' International seemed to have been dropped or at least shelved by the mid-1930.

At least two fundamental issues were discussed at the Sixth Conference, both concerning work among maritime transport workers. The first one reflected the focus of the IPAC-TW on agitation and propaganda among 'coloured' and colonial seamen, the second one redefined the work of the Interclubs and is discussed below in Section 4.3. Both issues were closely tied to achievements of the IPAC-TW since its Fifth Conference in 1928. A positive aspect was the strengthening of its regional units in Latin America and the Far East as well as the establishment of red seamen's unions in France, Greece and the USA. On the negative side were the deploring, if not pathetic, records of the revolutionary trade union opposition in most land-based transport workers' unions. Even worse, the IPAC-TW headquarters had to admit that it lacked reliable and stable connections to most of its secretariats and its sections. Inter-regional cooperation during strikes was weak if non-existing, and demonstrated the incapability of the revolutionary trade union opposition groups to embrace the Strassburg Theses. ${ }^{29}$

The Sixth Conference adopted a resolution which confirmed the 'United front from below'-tactic but added a global twist to them as work among colonial and 'coloured' maritime workers were to constitute a core activity. The IPACT-TW and its sections were compelled to apply an uncompromising stance against discrimination, racism and segregation; the revolutionary opposition was directed to fight for equal pay for equal work and to stand up against white chauvinism. The 1930 Resolution identified the shipping industry as the key

29 Resolution über die Tätigkeit des IPAKT und seiner Sekretariate und über die organisatorischen Aufgaben der revolutionären Transportarbeiter [1930], 534/5/214,137-14O, RGASPI. 
arena for prospective agitation. 'Coloured' crews on ships under a European flag, the resolution highlighted, received up to 50 percent less in wage than white mariners; on Japanese ships, Korean crews received 20 percent less than Japanese mariners. Therefore, the 1930 Resolution ordered the revolutionary opposition to systematically press for equal pay for equal work when the unions were negotiating tariffs and agreements with the shipping industry. ${ }^{30}$

The 1930 Resolution also addressed some specific tasks of the revolutionary opposition in the maritime transport workers' unions. In Japan, their objective was to fight against the 'social fascist' Japan Seamen's Union as well as the Japanese shipping industry and their 'chauvinist' policies towards Chinese and Korean seamen. In addition, the Japanese revolutionary opposition groups were ordered to assist Korean seamen to set up revolutionary nuclei. The sections in Britain, France, Germany, the Netherlands, Norway, Sweden, and the USA were instructed to focus on organising 'coloured' seamen and to ensure that 'coloured' seamen were included in the tariffs and agreements and were treated as equals on board the ships. ${ }^{31}$

\subsection{The 1930 Resolution on the Interclubs}

The Sixth Conference was the first one to elaborate specific instructions for the Interclubs. There existed already 19 Interclubs outside Soviet Russia by 1930 (see Map 1), all of them lacking guidelines and general instructions. Consequently, the closure of the Port Bureaus and the opening of new Interclubs in Western Europe, Australia and the USA necessitated a definition of their obligations and tasks. (The eleven Soviet Interclubs were not under the surveillance of the IPAC-TW. $)^{32}$

A first step towards streamlining the operations of the Interclubs was taken in March 1930. With the exception of the Hamburg Interclub, none of them kept any track of their activities and neither did they inform Moscow about their work. As a corrective measure, the IPAC-TW headquarters "categorically insists that each International Club must keep a systematic account of its activities" that "should be sent without fail every month" to Moscow. The "systematic account" entailed a 2o-point list of statistical data to be collected, among others (1) Number of boats, sailing under the various flags, entering the

30 Resolution über die Tätigkeit des IPAKT und seiner Sekretariate und über die organisatorischen Aufgaben der revolutionären Transportarbeiter [1930], 534/5/214, 141, RGASPI.

31 Resolution über die Tätigkeit des IPAKT und seiner Sekretariate und über die organisatorischen Aufgaben der revolutionären Transportarbeiter [1930], 534/5/214, 142-143, RGASPI. "Die Internationalen Klubs," in: Verkehrswirtschaft und Lage der Transportarbeiter [1930], 33-36, 534/5/214, 178-181, RGASPI. 


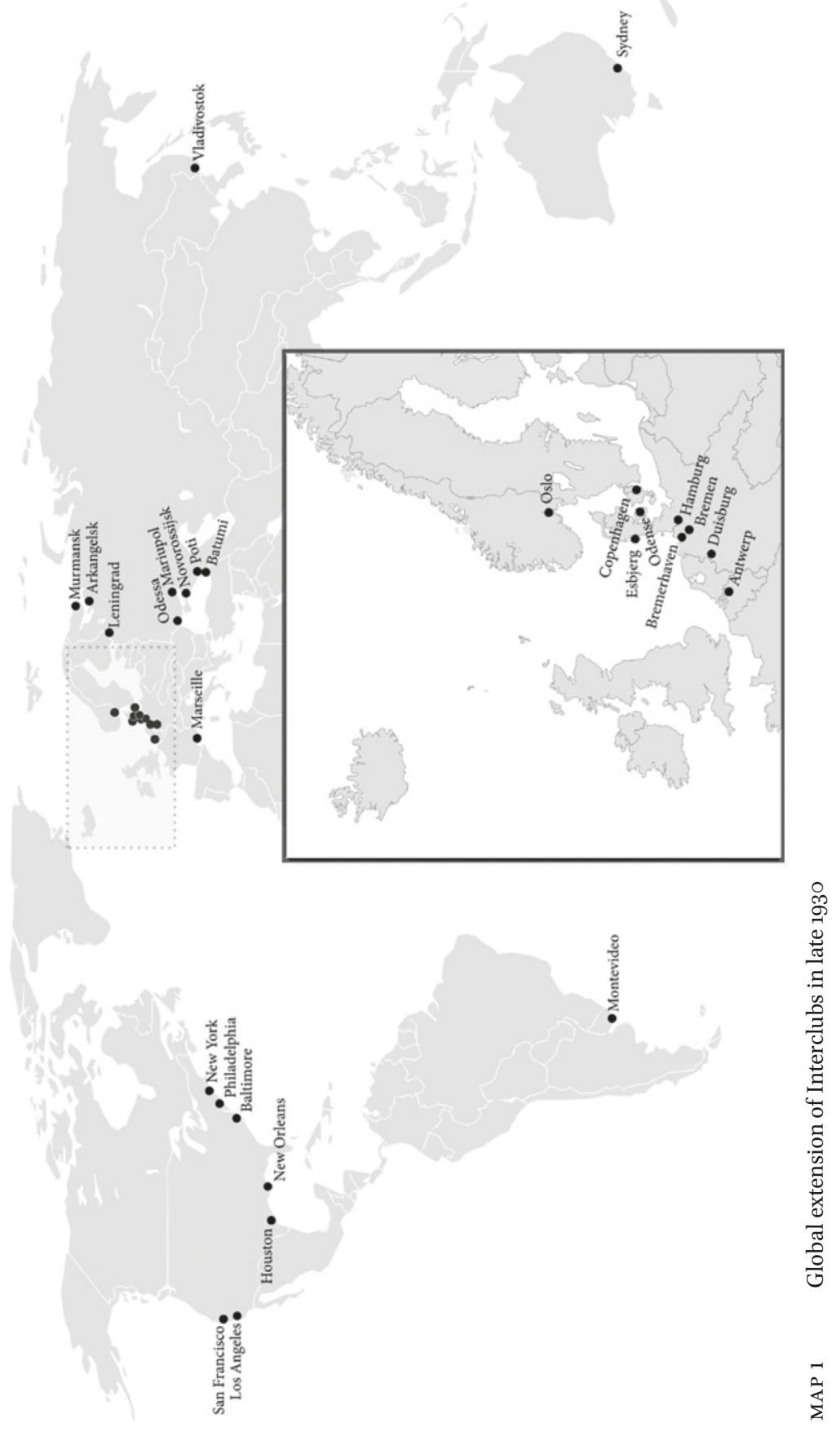


port; (2) Number of seamen visiting the Club, giving figures for each nationality separately; (3) Number of demonstrations, showing number of participants and why organised; and (4) Number of meetings, number attended, subjects of reports, speeches, by seamen, giving information as to nationality and resolutions adopted. In addition, the Interclubs were instructed to forward information on (5) number of vessels visited as well as number of ship's libraries organised (7), number of ship nuclei organised (10), number of members of revolutionary opposition and revolutionary unions in the given port (12), contact with other International Clubs (15), and leaflets, posters, etc issued by the Club (21). Moreover, the Interclubs were ordered to photograph all interesting events "in the mass work of the International Clubs" and forward the photographs to the IPAC-TW headquarters. ${ }^{33}$

It is unclear if any of the Interclubs ever complied with the March 1930 instructions. A few of them did send some data on their activities to Moscow that was analysed in an internal assessment on the Interclubs. If they ever forwarded photographs is not known and I have (so far) found any traces of them in the Comintern Archives (apart from a few unidentified ones depicting activities in Soviet Interclubs). Nevertheless, the statistical data and activity reports by the Interclubs revealed that that most of them were engaged in establishing revolutionary nuclei, although only the Hamburg Interclub as well as the clubs in North America had registered any success in their activities by 1930. A positive sign was also the start of work among black, Chinese and Philippine seamen by the US Interclubs, among Indian and Arab seamen in British ports, and among Chinese seamen by the Hamburg Interclub. A negative aspect were police raid and mob-attacks on the Interclubs and their functionaries in Hamburg, Baltimore, New Orleans, San Francisco, and San Pedro. In the USA, especially, both the police and the white mob often interrupted inter-racial meetings and gatherings of the Interclubs. ${ }^{34}$

The Sixth Conference also discussed a draft for instructions to the Interclubs. Echoing earlier regulations for the Port Bureaus, the instructions contained few concrete directives apart from one paragraph highlighting the central role of the Interclubs as inter- and transnational communication centres. This had not been achieved so far, the instructions noted, and urged the Interclubs to pay utmost attention on this task. ${ }^{35}$

33 Instructions, dated 21.3.1930, 534/5/217, 28, RGASPI.

34 "Die Internationalen Klubs," in: Verkehrswirtschaft und Lage der Transportarbeiter [1930], 33-36, 534/5/214, 180-181, RGASPI.

Resolution über die Interclubs, 534/5/214, 126-130, RGASPI. 


\subsection{Outlining the 'Basic Principles' for the 'Red Marine Workers' International'}

Among the documents filed in the Comintern Archives is a three-page typewritten text with handwritten corrections, titled 'Basic Principles (Draft Decision)'. In essence, the text is a detailed blueprint for the setup of a 'Red Marine Transport Workers' International'. The text seems to have been drafted in 1930 and outlines the objectives and organisational structures of an organisation for the unification of "seamen and dockers, and likewise the workers employed on the international water ways eonneeted with [corrected: working for] marine transport." In fact, a closer examination of the document reveals that it provided the framework for the (yet to be established) red "Marine Workers' International."36

It is likely that the 'Basic Principles'-document is linked to decisions made by the ECCI in July 1930. The Political Commission of the ECCI backed the idea of establishing a Seamen's International and ordered the RILU at its meeting on 3 July to initiate the process and to report on its activities at the next session of the Political Secretariat of the ECCI. ${ }^{37}$ Three weeks later, the Political Secretariat approved the plan, ordered the RILU Secretariat to raise the question at the forthcoming conference of revolutionary transport workers (see below), and to draft an outline of work of the new organisation. ${ }^{38}$ Most probably, therefore, the 'Basic Principles' was the document the RILU Secretariat drafted after it being ordered to do so by the ECCI.

The first part of the document sketches the relationship between the new International and the RILU. "The Marine Workers' International is affiliate to the R.I.L.U, wholly accepts its Constitution, and submits to all decisions of the R.I.L.U., the international congresses and conferences." This paragraph clearly indicated a hierarchical relationship as the 'Marine Workers' International was to be subordinated to the RILU. Independent red unions and revolutionary minorities were to affiliate with the new International although the latter ones were to remain inside the 'reformist unions'. The executive organ of the new International "is to be situated in London or Hamburg" - indicating that a final decision on the headquarters of the 'Marine Workers' International' was still on the table when the 'Basic Principles' were drafted. Important, however,

36 Basic Principles (Draft decisions), 1, 534/5/219, 81, RGASPI. Hereafter: Basic Principles (Draft Decision), the pagination refers to the page number of the document.

37 §5, Frage der Bildung einer Seeleute-Internationale, Protokoll Nr 70 der Sitzung der Politischen Kommission des EKKI vom 3. Juli 1930, 495/4/41, RGASPI.

38 §2, Frage der Gründung einer Seeleute-Gewerkschaftsinternationale, Protokoll Nr 69 der Sitzung des Politsekretariats des EKKI am 23. Juli 1930, 495/3/170, RGASPI. 
were its links to Moscow: "In order to coordinate its actions with the R.I.L.U. and for the speedy settlement of all question arising, the Executive Committee of the International is to have representation in Moscow," i.e., a bureau either in connection with the IPAC-TW or the RILU Secretariat. ${ }^{39}$

The launching of the new International was to be a two-stage process. An "Organisational Committee" was to be nominated at the "Second International Conference of Marine Workers", whose task it was to work for the organisation of the International and to call for a world congress where the International was to be constituted "not later than May 1931 in Hamburg." 40 The "Second International Conference" was the conference organised by Albert Walter in Hamburg in October 1930, thus indicating that the 'Basic Principles' were drafted before the event.

According to the 'Basic Principles', the Organisational Committee, i.e., known as the '(Provisional) Executive Committee of the International of Seamen and Harbour Workers' after its nomination in October 1930, was to include representatives of the RILU, the IPAC-TW, the USSR, Germany, Britain, France, the USA, Latin America, China and the "India Seamen's Union (London)." The Organisation Committee was to direct the work of the national sections of the (yet to be established) International as well as to "take over the network of International Seamen's Clubs." Consequently, the new International was projected as the new platform for the radical waterfront whereas the IPAC-TW "remains only as a Committee of railwaymen and transport workers." 41

The headquarters or "Bureau" of the Organisational Committee was to be placed in Hamburg. As understood from the 'Basic Principles', the Bureau was to be operated by the German member of the Committee, i.e., Albert Walter, while "the other members work in their countries as representatives of the Committee along the directions and instructions of the latter." Neither the Bureau nor the Committee were to act independently; following the typical outline of the Comintern-apparatus, the Committee was to have a representative in Moscow. ${ }^{42}$

Apart from preparing the World Congress, the "most urgent task" of the Committee "should be the complete crystallisation [...] of the independent revolutionary seamen's unions of Britain, France, Italy, India," i.e., to compel the formation of red unions in accordance to the RILU directives. Another

\footnotetext{
39 Basic Principles (Draft Decision), 1.

40 Basic Principles (Draft Decision), 1, 4.

41 Basic Principles (Draft Decision), 2.

42 Basic Principles (Draft Decision), 2.
} 
"most urgent task" was the formation of "national centres" for revolutionary minorities within the unions, i.e., the unification of the opposition groups. To achieve this end, the Committee was to commence the "mass publication" of leaflets, pamphlets and bulletins in German, French, English, Spanish, Norwegian, "and other languages." 43

The World Congress was to be preceded by an international political propaganda campaign orchestrated by the Committee and carried out by the national red unions and opposition groups as well as the Interclubs. The core message of the campaign was 'Leave the ITF': The revolutionary opposition was to press the national unions to vote for affiliating with the new International. ${ }^{44}$

Interclubs and 'coloured' (i.e., black) seamen were earmarked as special targets for the International. Echoing earlier IPC-TW/IPAC-TW visions, the Interclubs were projected as "the centres of mass agitation"; therefore, new Interclubs were to be set up "without fail" in Antwerp, London, Montevideo, Rotterdam, Thessaloniki, Singapore, "and elsewhere." Linking up with earlier memoranda, perhaps even indicating Ford's participation in drafting the 'Basic Principles' (?), work among 'coloured' (black) seamen was to be given top priority. Therefore, the International was urged to "consider it necessary to have special organisers" in the ports of the colonial metropoles to conduct work among 'coloured' (black) seamen. ${ }^{45}$

\subsection{The Road to Hamburg}

At the same time as the comrades gathered Moscow and discussed the activities of the Interclubs in April 1930, a commission assessed the activities of the Hamburg Port Bureau. It is unclear who had instigated the assessment and why it was conducted. Perhaps it was part of the ongoing revision of the IPAC-TW as the commission's report was sent to Moscow. In any case, the report raised some alarming issues. Most critical was the increasing external attacks and restrictions upon the Hamburg Interclub. These had detrimental consequences for the Hamburg Port Bureau and Albert Walters' international communication network. Communist agitation on board German merchant ships was increasingly challenged by the Nazi seamen's organisation. Seamen who were known to be communists were disregarded and not hired by the shipowners. Walter's network was shrinking and he was urged to establish an

\footnotetext{
43 Basic Principles (Draft Decision), 2-3.

44 Basic Principles (Draft Decision), 3.

45 Basic Principles (Draft Decision), 3.
} 
'illegal' international communications network that was capable of taking action in case of a crisis. ${ }^{46}$

Equally disturbing was the extensive use of the premises of the Hamburg Interclub by the local party and land-based communist organisations. The assessment report critically remarked that the party did not render any assistance to the Interclub. Neither did the party pay rent when using the Interclub nor did it have any functionary who was capable of working on the waterfront. Third, the Interclub, in turn, was criticised for not having paid any attention on work among harbour workers. Fourth, and in line with the new instructions on discussion in Moscow, the Interclub was to establish an international communications network and link up with all other clubs. ${ }^{47}$

Albert Walter most likely backed the outspoken criticism articulated in the assessment report. He had more than once declared that the premises at Rothesoodstrasse were the domain of the radical mariners, not the party. In fact, the assessment report strengthened his ambition to turn Rothesoodstrasse into the centre of the envisioned Seamen's International. Furthermore, Walter informed Moscow that the international call for attendees to the conference was in progress. ${ }^{48}$

A decision of the ECCI on 23 July 1930 set stage for the final act when it sanctioned the plan for an International for maritime transport workers. The ECCI projected the official launching of the new organisation to take place at the international conference scheduled to commence at the Hamburg Interclub in August $1930 .{ }^{49}$ However, in August it was realised that the Maritime Workers' Conference had to be postponed until October; instead, Walter organised two mass rallies in Hamburg in early August to manifest the support the Sixth Conference of the radical transport workers that recently had gathered in Moscow. About 2,80o seamen participated at first rally on 9 August, Walter claimed in his report. The second one on 10 August counted almost 10,000 participants who marched through the streets of Hamburg, boasted Walter. A sizeable number of them mustered afterwards at an international meeting at the

46 Bericht der eingesetzten Untersuchungs-Kommission zur Kontrolle der Arbeit und aller damit zusammenhängenden Aufgaben des Hafenbüros Hamburg, 28.7.1930, 534/5/216, 40-51, RGASPI.

47 Bericht der eingesetzten Untersuchungs-Kommission zur Kontrolle der Arbeit und aller damit zusammenhängenden Aufgaben des Hafenbüros Hamburg, 28.7.1930, 534/5/216, 40-51, RGASPI.

48 Internationales Hafenbüro für Seeleute, Monatsbericht für Mai 1930, 534/5/216, 25-26, RGASPI.

49 Protokoll Nr 89 der Sitzung des Politischen Sekretariats des EKKI am 23.7.1930, 495/3/170, RGASPI. 
Interclub. When closing the event, Walter read out in front of some 1,6oo participants the official declaration that the 'Fighting International of the Maritime Transport Workers' (Kampfinternationale aller Seetransportarbeiter) was to be launched in Hamburg on 1 October 1930. ${ }^{50}$

50 Internationales Hafenbüro Hamburg, Monatsbericht August-September 1930, 534/5/216, 67-69, RGASPI. 